УДК 336.614 .4

\title{
ВПЛИВ ПАНДЕМІї ВІРУСУ COVID-19 НА МИТНУ ПОЛІТИКУ УКРАЇНИ
}

\section{THE IMPACT OF THE COVID-19 VIRUS PANDEMIC ON UKRAINE'S CUSTOMS POLICY}

\author{
Дубик Вікторія Яківна \\ кандидат економічних наук, доцент, \\ Львівський національний університет імені Івана Франка \\ ORCID: https://orcid.org/0000-0002-3475-4156 \\ Замрій Остап Михайлович \\ студент, \\ Львівський національний університет імені Івана Франка \\ ORCID: https://orcid.org/0000-0002-5317-5635 \\ Dubyk Viktoriia, Zamrii Ostap \\ Ivan Franko National University of Lviv
}

\begin{abstract}
В умовах розповсюдження коронавірусного захворювання у світі та поширення його впливу на усі ссрери життя населення, актуальним зараз $є$ аналіз стану митної політики України в умовах пандемії COVID-19, як однієї з основних сорер забезпечення економічного розвитку держави. У статті досліджено зміни, що відбулись у вітчизняній митній справі через виникнення уханської недуги. Виявлено внутрішні проблеми митної політики, викликані коронавірусом. Запропоновано шляхи вирішення цих проблем та зазначено методи покращення митної справи. Опрацьовано показники статистики зовнішньоекономічної діяльності України за 2019-2021 роки та проаналізовано їхню динаміку. Визначено зовнішні трансформації митної політики, які відбулись через розвиток вірусу та вказано способи подолання негативних наслідків пандемії у митній системі.

Ключові слова: митна політика, зовнішньоекономічна діяльність України, митна служба, пандемія вірусу COVID-19, коронавірусна інфрекція, товарообіг, імпорт, експорт.
\end{abstract}

В условиях распространения коронавирусного заболевания в мире и распространения его влияния на все сореры жизни населения, актуален анализ состояния таможенной политики Украины в условиях пандемии COVID-19, как одной из основных сфер обеспечения экономического развития государства. В статье исследованы изменения, произошедшие в отечественном таможенном деле из-за возникновения уханского недуга. Выявлены внутренние проблемы таможенной политики, вызванные коронавирусом. Предложены пути решения этих проблем и указаны методы ее улучшения. Проработаны показатели статистики внешнеэкономической деятельности Украины за 2019-2021 годы и проанализирована их динамика. Определены внешние трансформации таможенной политики, которые произошли из-за развития вируса и указаны способы преодоления негативных последствий пандемии в таможенной системе.

Ключевые слова: таможенная политика, внешнеэкономическая деятельность Украины, таможенная служба, пандемия вируса COVID-19, коронавирусная инсрекция, товарооборот, импорт, экспорт.

The biggest and most global problem in 2019 was the discovery of a new virus in China. First Asia, then Europe, then America and then all the other continents. The coronavirus has spread to all parts of the world. It affected all spheres of people's lives. COVID-19 influenced politics, economics, medicine and other government.Everyone who lives on a continent has felt the impact of the pandemic on their lives. Customs policy is one of the main components of the economic structure of the country and an important factor in the economic growth of any state. With its help, the export and import of countries increases, business improves, the population receives the resources it needs, countries form economic relations, create economic alliances, sign various agreements and develop the international market. The virus has brought negative changes in customs policy and thus spoiled all these indicators. To find out the scale of the pandemic, to investigate the problems caused by the virus and to suggest ways to solve them and ways to improve customs in this situation, we need to look at our country. This will make it possible to follow the statistical dynamics and determine the impact of the coronavirus on the customs system. We researched scientific materials, media articles and customs publications. In this article we have considered the external and internal 
situation of Ukraine's customs policy. In the internal state of customs policy, we considered how the pandemic has changed the structure of the customs service, customer service methods, working conditions of customs officers, IT system and more. We have proposed ways to solve these problems and ways to improve the internal state of customs policy. In the external state of customs policy, we defined how the coronavirus affected the indicators of Ukraine's foreign economic activity in 2019-2021, domestic customs legislation, the level of economic relations with other partner countries of our country and more. We offered ideas for correcting problematic situations in the field of foreign policy and customs development. Based on all the research, we formed conclusions and suggestions.

Keywords: customs policy, foreign economic activity of Ukraine, customs service, COVID-19 virus pandemic, coronavirus infection, trade, import, export.

Постановка проблеми. Пандемія вірусу COVID-19 протягом 2019-2021 років встигла поширитись на всі світові континенти. Україна відчула перші зміни, що принесло захворювання з Китаю в кінці 2019-го. За три роки коронавірус зміг вплинути на всі складові державної політики України. Найбільших збитків він приніс митній справі. Тож доцільно проаналізувати стан митної політики України за 2019-2021 роки, виявити проблеми, завдані вітчизняній економіці загалом та митній сфрері зокрема і розглянути методи їх подолання.

Аналіз останніх досліджень та публікацій. Питанням розвитку митної політики України під час пандемії вірусу COVID-19 займались такі вітчизняні вчені та науковці: Дубич К. В., Калуга Н. В., Караваєв Т. А., Ковальчук О. В., Прус Л. Р. та інші. Дослідження показників зовнішньоекономічної діяльності в коронавірусний період проводили Державна митна служба України та українські ЗМІ.

Формування цілей статті. Метою дослідження $€$ визначення впливу пандемії вірусу COVID-19 на вітчизняну митну політику через аналіз внутрішніх та зовнішніх показників митної справи.

Виклад основного матеріалу. Найбільшою загрозою кінця 2019 року стало захворювання, що почало поширюватись в місті Ухань, Китайської Народної Республіки. Поширення його в Азії спершу викликало занепокоєння лише у медиків та керівництва держав-сусідів Китаю. Тоді спалах вірусу в одному місті насторожував лише близькі за розташування до нього країни та їхнє населення. У 19-ому ніхто й подумати не міг, що окрім надзвичайно великих людських втрат, недостатнього рівня медицини для подолання захворювання, слабкого забезпечення медичними ресурсами громадян, вірус зможе стати причиною ще однією світової-економічної кризи.

Протягом 2019-2021 років коронавірус зачепив усі галузі життя населення: від питань економіки та політики країни, до особистих справ кожної людини. Однією зі сорер, яка зазнала найбільше потрясінь від уханської недуги стала митна політика. Кожна країна зазнала різних змін у митній системі: одним це принесло невеликі негативні наслідки, інші ж до сьогодні шукають методи вирішення митних проблем, викликаних захворюванням.

Розглянемо як така глобальна ситуація відобразилась на митній справі України. Пандемія вірусу COVID-19 кардинально змінила внутрішній та зовнішній стани митної політики України. Внутрішній стан митної політики передбачає зміни у: діяльності митної служби країни, методах обслуговування населення, способах обміну інсоормацією між громадою та митницею, правилах поводження в адміністративних будівлях та на митних постах для відвідувачів, умовах роботи для митних працівників та інше. Зовнішній стан митної політики характеризується трансформаціями: митного законодавства, стану економічних відносин 3 країнами та міжнародними організаціями, показників зовнішньоекономічної діяльності держави та іншим.

Щоб проаналізувати ефективність здійснення Урядом та митними органами зовнішньої митної політики, достатньо розглянути основні показники зовнішньоекономічної діяльності країни. 3 них ми дізнаємось про вплив пандемії на митну систему України. Що ж до внутрішнього напряму політики, то можливості порівняти статистичні дані по роках немає. Проте завдяки статтям ЗМІ та публікаціям Державної митної служби України ми маємо змогу дослідити вплив коронавірусної інфекції на митну політику всередині країни.

Тож пандемія зумовила виникнення таких проблем у внутрішньому стані митної політики України:

- зменшення прибутковості бізнесу через закриття деяких митних постів та введення карантинних обмежень;

- посилення вимог для юридичних та фрізичних осіб при проходженні митного контролю і ускладнення його;

- неготовність митної служби перейти у дистанційний режим обслуговування громадян;

- відсутність належного фрінансового забезпечення, яке б дозволило швидко переорієн- 
туватись митниці, відповідно до погіршення економічного стану в країні;

- збільшення скарг учасників митного процесу на діяльність митної системи;

- зростання випадків контрабанди та корупції в органах митної служби;

- недостатній рівень інфрормування населення та власників підприємств про правила проведення митного процесу у період карантину;

- погана обізнаність працівників митниці щодо виконання посадових обов'язків у період пандемії;

- низький рівень епідеміологічного захисту працівників митниці, що призвів до захворюваності вірусної інфекцією серед них;

- повільний етап проведення вакцинації серед працівників митниці;

- інші.

Для вирішення внутрішніх проблем, викликаних вірусом, та вдосконалення стану митної політики українській владі та митним органам необхідно вжити наступних заходів:

- бути готовими при погіршенні епідеміологічної ситуації в країні перейти в онлайнрежим роботи митної служби;

- задля безпеки населення організувати повноцінний його прийом митними органами через дистанційні канали обслуговування або ж за допомогою відповідних методів, що дозволяють дотримуватись всіх карантинних вимог;

- 3 метою захисту працівників обмежити можливість відвідування основних митних установ громадянам;

- налагодити прийом та видачу документів через спеціальні скриньки, призначені для обміну інфрормацією між населенням та митницею;

- знайти нові IT-рішення, що дадуть змогу спростити митний процес та дозволять населенню і бізнесу вирішувати більшість проблемних питань через веб-сайти та додатки митної служби;

- покращити онлайн-підтримку та «гарячу лінію» митниці, щоб фрізичні та юридичні особи могли проконсультуватись у разі потреби;

- вдосконалити засоби особистого захисту працівників, що працюють 3 населенням на митних постах та закупити якісне обладнання для проведення температурного скринінгу;

- закріпити сталий графрік дезінфрікування приміщень, де знаходяться митники та відвідувачі митниці;

- створити резерв медичних засобів та ліків, щоб при необхідності забезпечити ними митні органи;

- інші [3].
Для виявлення пандемічних проблем, що склались у зовнішньому напрямі митної політики, варто розглянути основні показники зовнішньоекономічної діяльності України. Для цього дослідимо динаміку товарообігу, експорту та імпорту України за 2019-2021 роки та дізнаємось як поширення COVID-19 відобразилось на вітчизняній митній справі. 3 показниками товарообігу України за 2019-2021 роки можемо ознайомитись на рис. 1.

У 2019 році товарообіг України склав 111997 млн дол, початок 2020-го розпочався з розповсюдження вірусу COVID-19 по всьому світу і наша країна не стала винятком. Спершу вплив пандемії на зовнішньоекономічну діяльність держави не був відчутним, але весною 2020 року Уряд України встановив карантин, який обмежив діяльність вітчизняного і закордонного бізнесу, ускладнив торговельні процеси та призупинив діяльність багатьох митних постів. Обмеження протягом року то посилювали, то послаблювали, відповідно до епідеміологічного стану в Україні. В кінці року це принесло невтішний результат - зменшення обсягу товарообміну на 1429 млн дол (-1\%). Літо 2021 року дало надію на відновлення міжнародної торгівлі, адже Україна та їі країни-партнери почали поступово знімати противірусні обмеження, стимулювати імпорт і експорт та дозволяти населенню перетинати кордон. Попри послаблення карантину, результат осені 2021го всеодно приніс негативний результат - зменшення товарообігу ще на 7190 млн дол (-7\%) [4]. До 2022 року залишається ще кілька місяців, новий штамп Омікрон щораз швидше розповсюджується і чекати позитивних змін у зовнішньоекономічній діяльності поки не варто.

Експорт та імпорт фрормують товарообіг України, тому варто розглянути їхню статистику (рис. 2) та (рис. 3).

3 рис. 2 видно зміни, які відбулись у експорті нашої країни за 2019-2021 роки. У 2019 році Україна продала товарів закордон на суму 54588 млн дол, у 2020 році - на 50178 млн дол (-8\%), у 2021 році - на 49324 млн дол (-2\%). Зменшення обсягу експорту товарів відбулось через введення карантинних обмежень від торговельних країн-партнерів України, призупинення діяльності багатьох підприємств, що займались постачанням продукції закордон, зменшення потреби закупівлі сировини з-за кордону через складну ситуації у світі, зниження міграційних процесів населення та ускладнення митного контролю [2].

Окрім негативної експортної динаміки, вірус COVID-19 вплинув і на зовнішньоекономічні 


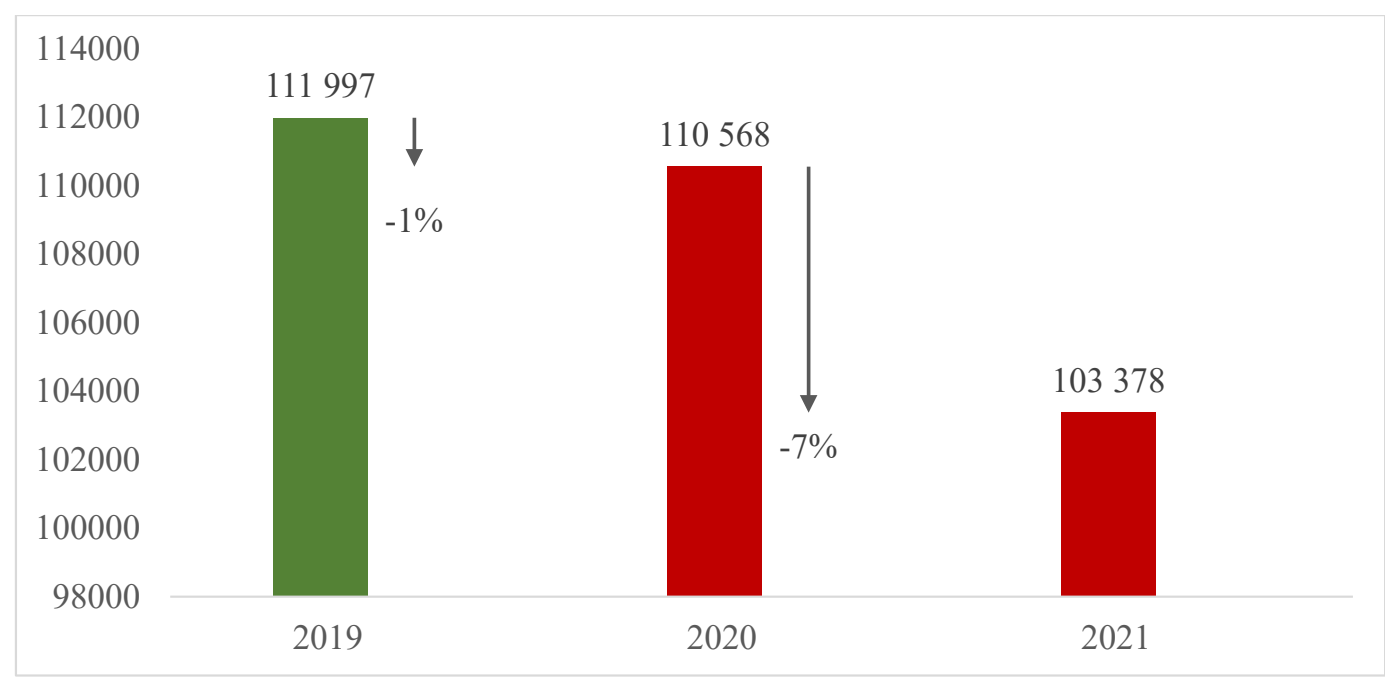

Рис. 1. Товарообіг України за 2019-2021 роки, млн дол

Джерело: сформовано за даними [4]

*дані 2021 року вказані за період січень-листопад

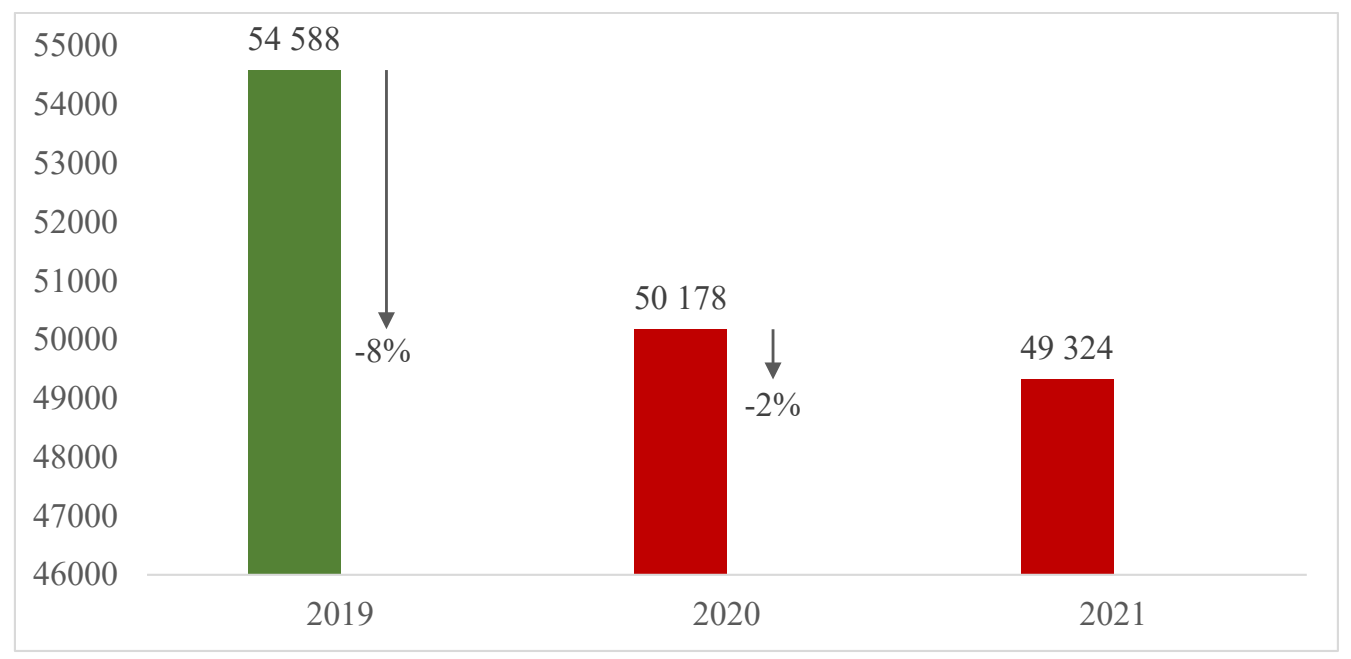

Рис. 2. Експорт України за 2019-2021 роки, млн дол

Джерело: сорормовано за даними [4]

*дані 2021 року вказані за період січень-листопад

відносини України із зарубіжжям. У 2019 році топ країн-партнерів України 3 експорту мав наступний вигляд: Китай, Польща, Російська Федерація, Туреччина та Італія. Протягом 2020-2021 року позиції країн змінювались і зараз вони розміщуються таким чином: Китай, Італія, Польша, Російська Федерація та Туреччина. Як бачимо з топу, Україна посилює зв'язок 3 європейськими країнами та послаблює його з Росією, що є позитивним чинником для нас.

Що ж рейтингу товарів, які Україна найчастіше експортувала у 2019 році, то їхнє розміщення наступне: зернові культури, чорні метали, жири та олії, руди та шлаки і електричні машини та запчастини до них. Станом на 2021 рік позиції товарів залишаються незмінними, тобто пандемія ніяк не вплинула на них.

Дивлячись на рис. 3, можемо стверджувати, що імпорт України протягом 2019-2021 років лише погіршувався. У 2020 році у порівнянні 32019 роком він зменшився на 2981 млн дол (-5\%), у 2021 році у порівнянні 32020 роком - ще на 3355 млн дол (-6\%). Поясненням такої ситуації є заборона ввезення певних видів товарів, зменшення потреб населення під час пандемії та розбіжності в економічних відносинах між країнами. 


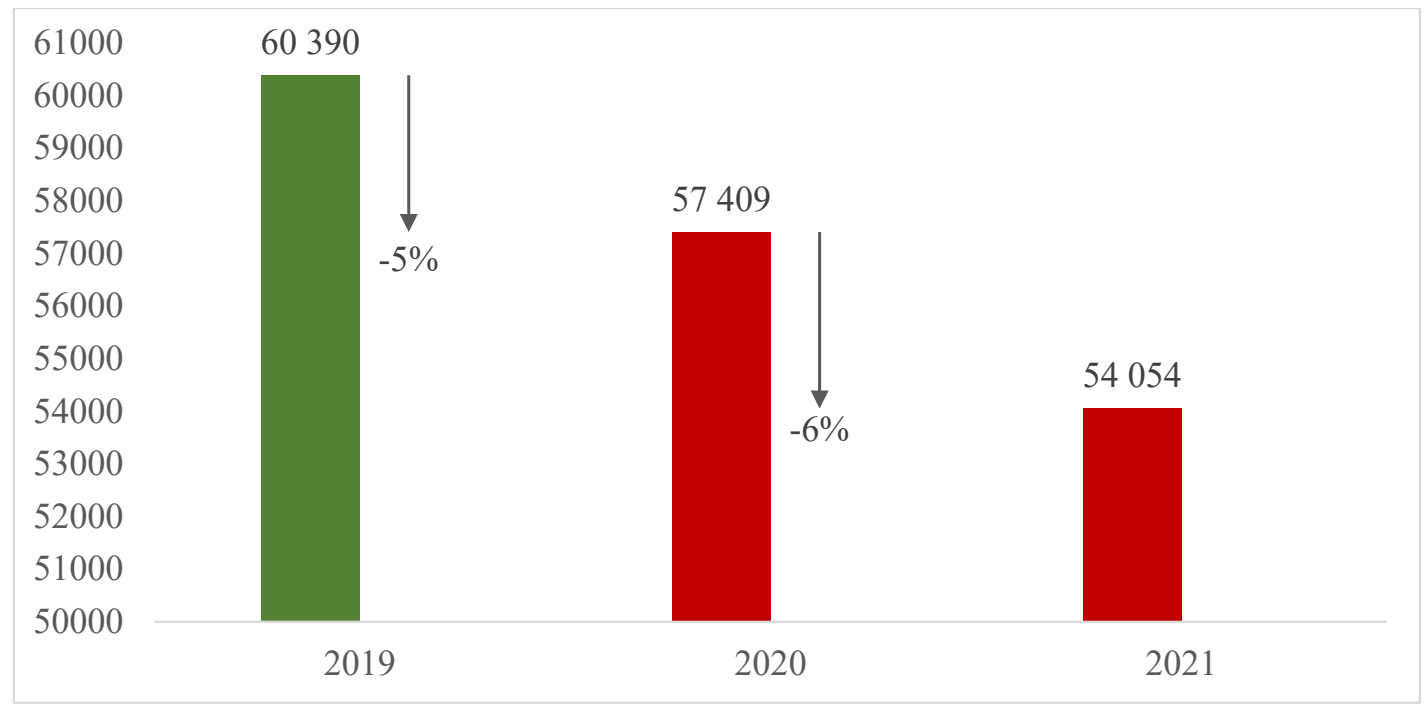

Рис. 3. Імпорт України за 2019-2021 роки, млн дол

Джерело: сорормовано за даними [4]

*дані 2021 року вказані за період січень-листопад

Топ країн-партнерів України з постачання продукції зараз виглядає так: Китай, Російська Федерація, Німеччина, Польща, Білорусія. У 2019-2020 роках країни розподілялись аналогічно.

Що ж до списку товарів, які наша країна найбільше завозить з-за кордону, то він такий: настта та паливо, автотранспорт, реактори та їхнє обладнання, електромашини та запчастини до них, пластмаса та матеріали 3 неї. у 19-ому лише автомобілі займали нижчу позицію ніж сьогодні. У зв'язку з введенням обмежень на пересування громадським транспортом, багато людей почали задумуватись над купівлею власного авто [4].

Спираючись на статистику зовнішньоекономічної діяльності, можемо визначати наступні проблеми, що викликав коронавірус у зовнішньому напрямі митної політики:

- невідповідність законодавства тій ситуації, що склалась у митній політиці;

- відсутність повноцінних альтернативних методів проведення митного процесу у пандемічний період;

- зменшення обсягу надходжень митних платежів через зменшення імпорту та експорту;

- зниження рівня товарообігу;

- заборона власному населенню та іноземцям перетинати кордон;

- відсутність єдиної інфрормаційної системи 3 іншими країнами для полегшення ведення митного процесу;

- послаблення економічних відносин з країнами-партнерами;
- неготовність української влади формувати торговельні зв'язки з іншими країнами та економічними союзами в період пандемії;

- інші.

Для вирішення цих проблем та покращення стан зовнішньоекономічної діяльності країни потрібно:

- внести зміни до митного законодавства та інших нормативно-правових актів, відповідно до коронавірусної ситуації в країні;

- поступово послаблювати карантинні обмеження на митниці і стимулювати експорт та імпорт продуктів;

- дозволити 3 дотриманням карантинних правил та норм частині населення перетинати кордон;

- сорормувати методи для альтернативної роботи митниці на випадок погіршення епідеміологічного стану в країні;

- створити відділ митної служби, які буде займатись інтеграцією України в світову інорормаційну митну систему;

- поступово налагоджувати економічні відносини 3 країнами-партнерами нашої держави [1];

- інші.

Висновки. У 2021 році не залишилось жодної країни, яка б не відчула соціальноекономічних наслідків від пандемії вірусу COVID-19. Коронавірус вплинув на погіршення усіх фрінансових показників держав.

Митна політика стала однією зі сорер, якій уханська недуга принесла найбільше невтішних результатів. Внутрішній стан мит- 
ної справи Україна зазнав таких негативних наслідків: неготовність митної служби працювати у дистанційному режимі прийому громадян та обслуговування бізнесу, брак ресурсів для забезпечення діяльності митної системи та захисту митників від вірусу, поширення захворюваності серед працівників митниці, провальна робота із вакцинацією кадрового складу митниці та збільшення незадоволеності населення через дії влади та митних органів. Для вирішення цього потрібно: здійснити перехід у онлайн-режим роботи митниці, Уряду та митній службі якісніше проводити інсрормаційну роботу 3 населенням та кадровим складом щодо митної політики в умовах карантину та особистого захисту кожного від вірусу, перерозподілити фрінансові ресурси, щоб збільшити фрінансування митних органів.

У зовнішньому напрямі митної політики відбулись наступні зміни: протягом
2019-2021 років товарообіг України зменшився сумарно на 8619 млн дол (-8\%), експорт знизився на 5264 млн дол (-10\%), імпорт скоротився на 6336 млн дол (-11\%). Окрім цього, коронавірус приніс і такі результати: погіршення економічних відносин України 3 іiі країнами-партнерами, законодавча недосконалість, відсутність єдиної інфрормаційної митної системи. Щоб покращити зовнішній стан митної справи потрібно: відновити та налагодити партнерську співпрацю з іншими державами, покращити показники зовнішньоекономічної діяльності України за допомогою нових методів роботи митниці у період пандемії, вдосконалити законодавство, відповідно до ситуації, що склалась у світі.

Лише адаптувавшись до нових реалій і підлаштувавши митну політику до ситуації, що склалась, наша країна зможе успішно подолати наслідки пандемії та продовжити економічний розвиток.

\section{СПИСОК ВИКОРИСТАНИХ ДЖЕРЕЛ:}

1. Караваєв Т. А., Калуга Н. В. Митна справа в умовах COVID-19. ВICHИК КHTEУ. 2020. № 5. URL: http://visnik.knute.edu.ua/files/2020/05/06.pdf

2. Ковальчук О. В., Дубич К. В. Проблеми реформування державної служби в митних органах. Інвестиції: практика та досвід. 2021. № 15/202. URL: http://www.investplan.com.ua/pdf/15_2021/20.pdf

3. Прус Л. Р. Особливості здійснення державної митної справи в умовах пандемії COVID-19. Науководослідний інститут фріскальної політики. 2020. URL: https://www.ndifp.com/1322/

4. Показники зовнішньої торгівлі України // Державна митна служба України. URL: https://bi.customs.gov.ua/ uk/trade/

\section{REFERENCES:}

1. Karavaev T. A., Kaluga N. V. (2020) Customs in the conditions of COVID-19. BULLETIN KNTEU, 5. Retrieved from: http://visnik.knute.edu.ua/files/2020/05/06.pdf

2. Kovalchuk O. V., Dubych K. V. (2021) Problemy reformuvannia derzhavnoi sluzhby v mitnykh organakh [Problems of reforming the civil service in customs]. Investytsii: praktyka ta dosvid, 15/202. Retrieved from: http://www.investplan.com.ua/pdf/15_2021/20.pdf

3. Prus L. R. (2020) Features of the implementation of state customs in a pandemic COVID-19. Research Institute of Fiscal Policy. Retrieved from: https://www.ndifp.com/1322/

4. Indicators of foreign trade of Ukraine // State Customs Service of Ukraine. Retrieved from: https://bi.customs.gov.ua/ uk/trade/ 